\title{
Detailed energy efficiency strategies for converting an existing office building to NZEB: a case study in the Pacific Northwest
}

\author{
Ali Alajmi • Abby Short • Janna Ferguson • Kalina \\ Vander Poel • Corey Griffin
}

Received: 6 February 2019 / Accepted: 3 April 2020 / Published online: 22 May 2020

(C) The Author(s) 2020

\begin{abstract}
This paper is an attempt to identify a methodology for converting conventional energy consumption buildings to net-zero energy buildings (NZEB). The first step was rather different from the usual energy audit, which is to analyze a facility's energy consumptions from both macro- and micro-scales. To implement such an approach, a governmental office building (Metro) in Portland, OR, was chosen as a case study. After a building model was validated against a real measurement, it was then used to evaluate different energy efficiency strategies (EESs) so as to reduce the energy consumption. The EESs showed a reduction in energy use intensity (EUI) from 166 to $66 \mathrm{kWh} / \mathrm{m}^{2}$.year, which is $60 \%$ less than the current consumption. The remaining energy demand of the building will be compensated by implementing renewable energy technologies (RETs), namely photovoltaic. The photovoltaic (PV) panels showed viability since they will produce $532 \mathrm{MWh}$ on-site throughout the year, which is sufficient for the future remaining energy demand of the building (490.5 MWh). In conclusion, the simple
\end{abstract}

\section{A. Alajmi \\ Mechanical Engineering Department, College of Technological Studies, PAAET, Kuwait City, Kuwait}

\section{A. Alajmi $(\square)$}

Mechanical and Material Engineering Department, Portland State University, Portland, OR, USA

e-mail: alajmi@pdx.edu

A. Short · J. Ferguson · K. V. Poel · C. Griffin School of Architecture, Portland State University, Portland, OR, USA payback period (SPP) and the life cycle cost analysis proved the feasibility of EESs and RETs. Environmentally, a total of 106 tons of $\mathrm{CO}_{2}$ was prevented per year; in addition, 64.6 tons of $\mathrm{CO}_{2}$ will also be avoided by the PVs on a yearly basis.

Keywords Net-zero energy building (NZEB) · Energy efficiency strategies (EESs) · Macro- and micro-scales energy analysis $\cdot$ Renewable energy technologies $($ RETs) $\cdot$ Energy use intensity (EUI)

\section{Introduction}

Extending the life of an existing building by way of a renovation project has continually proven to be a smart and sustainable choice. Renovations require fewer materials than a new construction project while offering the opportunity to make the building significantly more energy-efficient. Also, the growth rate of commercial/ governmental floor areas in the USA, for instance, is relatively small, approximately $1 \%$ per year. A combination of these facts indicates that renovation yields a significant opportunity to reduce the overall environmental impact of buildings.

Buildings are claimed to be among the largest sources of greenhouse emission, estimated to be one third of the total emission (Levine et al. 2013). Such a considerable share of emissions has heightened the interest and attention in recent years among researchers and practitioners on the issue of net-zero energy building (NZEB) or zero energy buildings (ZEBs). The EU's Energy Performance 
of Buildings Directive (EPBD) specified that by the end of 2020 all new buildings should be "nearly net-zero energy buildings" (EPBD recast 2018). In the USA, the strategic goal of the Building Technologies Program of the US Department of Energy (DOE) is to achieve "marketable zero energy homes in 2020 and commercial zero energy buildings in 2025" (US DOE 2008). Similarly, the American Society of Heating, Refrigerating, and AirConditioning Engineers (ASHRAE) has assigned a target of net-zero energy buildings fulfillment by 2030 (ASHRAE 2008). The new definition of NZEB by DOE refers to "an energy-efficient building where, on a source energy basis, the actual annual delivered energy is less than or equal to the on-site renewable exported energy" (Peterson et al. 2015). Crawley et al. (2009) acknowledged four NZEB definitions: net-zero site energy, net-zero source energy, net-zero energy costs, and net-zero energy emissions. Therefore, different NZEB definitions are possible in conjunction with the country's political targets and specific conditions (Sartori et al. 2012; Marta and Graziano 2013).

Accordingly, the main aim of achieving NZEBs for many organizations (EBPD or DOE) is included in the newly designed buildings' standard. While these buildings may face challenges in terms of achieving NZEB, existing buildings face even more significant challenges. Existing buildings should thus undergo an energy auditing process (ASHRAE 100; 6 2006) and implement cost-effective energy efficiency strategies (EESs) to reduce building energy consumption before considering renewable energy as a complementary energy source. EESs include building envelopes, internal conditions, and building services systems (Li et al. 2013; Kapsalaki and Leal 2011; Rahman et al. 2010; Iqbal and Al-Homoud 2007; Mills et al. 2005; Lam et al. 2008); renewable energy technologies (RETs) include building integrated photovoltaic, wind turbines, solar thermal (solar water heaters), and heat pumps, as well as district heating and cooling (Li et al. 2013; Kapsalaki and Leal 2011).

Many studies have investigated the economic and environmental aspects of the NZEB (Cao et al. 2016; Belussi et al. 2019; $\mathrm{Li}$ et al. 2013). For instance, Kurnitski et al. (2011) studied an Estonian detached house's cost-optimal solutions and NZEB. The authors concluded that a nearzero energy performance level is not yet cost-optimal with current prices. Similarly, Hamdy et al. (Hamdy et al. 2013) applied a multi-stage simulation-based optimization method to find cost-optimal NZEB solutions by means of a case study of a single-family house in Finland. The authors reconnoitered different options for building envelope parameters, heat-recovery units, and heating/cooling systems, as well as various sizes of thermal and photovoltaic solar systems. The results showed that the optimal solution depends for the most part on the selected heating/cooling system and the escalation rate of the energy price. Pikas et al. (Pikas et al. 2014) also tried possible building fenestration design solutions. They analyzed certain alternative measures to achieve the NZEB. However, the results showed that NZEB solutions are not cost-optimal, but this should change shortly with the fall in renewable energy system prices.

On the other hand, other research studies have focused on the life cycle costs of buildings (Hasan et al. 2008; Kneifel 2010). For instance, Marszal and Heiselberg (2011) adopted the life cycle cost analysis of a multi-family NZEB in Denmark, addressing three levels of energy demand and three alternatives of energy supply systems. They found that to build a cost-effective NZEB, the energy use should be reduced to a minimum, leaving a small amount of leftover energy use to be covered by renewable energy generation. Another relevant example is Hasan et al. (2008), who implemented a combined simulation and optimization approach to minimize the life cycle cost of a single-family detached house in Finland. The combined approach enabled them to find optimized values of selected design variables in the building construction and HVAC system.

Based on the above discussions, most of the literature on NZEBs have focused on dwellings and newly designed buildings, whereas existing commercial/governmental buildings have received little attention. In addition, most of the measures for reducing the energy consumption of existing buildings involved increasing the thermal performance of the envelope and fenestration.

In this work, a macro- and micro-scales energy analysis of a relatively large building is presented; such an approach should identify opportunities for saving energy on the assigned main building as well as the adjacent structures. Also, the main energy consumption building(s) need to be looked at in a micro-scale which might need to be segregated into different activity types. This will require installing separate energy meters to give a realistic energy performance analysis which can be compared to similar typology building benchmarks.

In addition, such an approach assists in validating a building model using the measured data. Then, the energy analysis can suggest energy efficiency strategies (EESs) for reducing the building energy consumption to 
the lowest possible energy use intensity (EUI). The remaining energy demand by the building(s), after implementing all feasible EESs, will be supplied by renewable energy technologies (RETs). Such a methodology will enable clarifying the feasibility of converting a conventional energy building into an NZEB.

A case study of a mid-size existing governmental office building (Metro) in Portland, OR, has been chosen to implement the stated methodology, and a verified model of the studied building has been created by DesignBuilder (DesignBuilder Software 2016) for the mentioned purpose.

\section{Methodology}

One of the main challenges of evaluating the energy performance of an existing building(s) is the limited data available. Most of the existing buildings have only one electricity and gas meter. Therefore, to conduct a successful energy analysis on the goal of reducing its consumption, a proposed approach conducted in this study is to split it into a two-scale assessment. The first scale starts from an overall look at the building's site and energy consumption (macro-scale), and the second inside the building and its internal components (micro-scale).

\section{Macro-scale energy assessment}

At the macro-scale, the whole site, besides the main building(s), needs to be included in the assessment, such as adjacent and annex buildings. These building(s), such as annexes and car parks, might have more opportunities for saving energy than the main building(s). Also, their roof might have more space to be utilized for integrating renewable energy technologies (RETs).

At the beginning, the as-built drawings of the building site should be collected, if it is available, so as to examine all buildings that belong to the same owner or energy service provider. A site visit is needed to explore the site and meet the energy manager and the operation staff to collect more information about the facility. From the monthly energy consumption and climate data, it can be identified from the consumption how it reacts to the outside condition if the measuring source of energy consumption is weather-based, i.e., it is effected by the outside condition. Alternatively, the main energy consumption burden is from the internal load, i.e., lighting, office equipment, miscellaneous load, etc. (Geng et al.
2018). This macro-scale energy analysis varies depending on the climate of the analyzed building, its size, and the occupants' activity. Based on this approach, the energy audit team will be able to focus on the most effective energy efficiency measures (EESs) that would play a significant role in reducing building energy consumption. The above-discussed scale of assessment is illustrated in the flowchart below (Fig. 1).

Micro-scale energy assessment

In micro-scale assessment, the set of energy efficiency strategies that has been initially specified based on the macro-scale evaluation needs to be verified. One

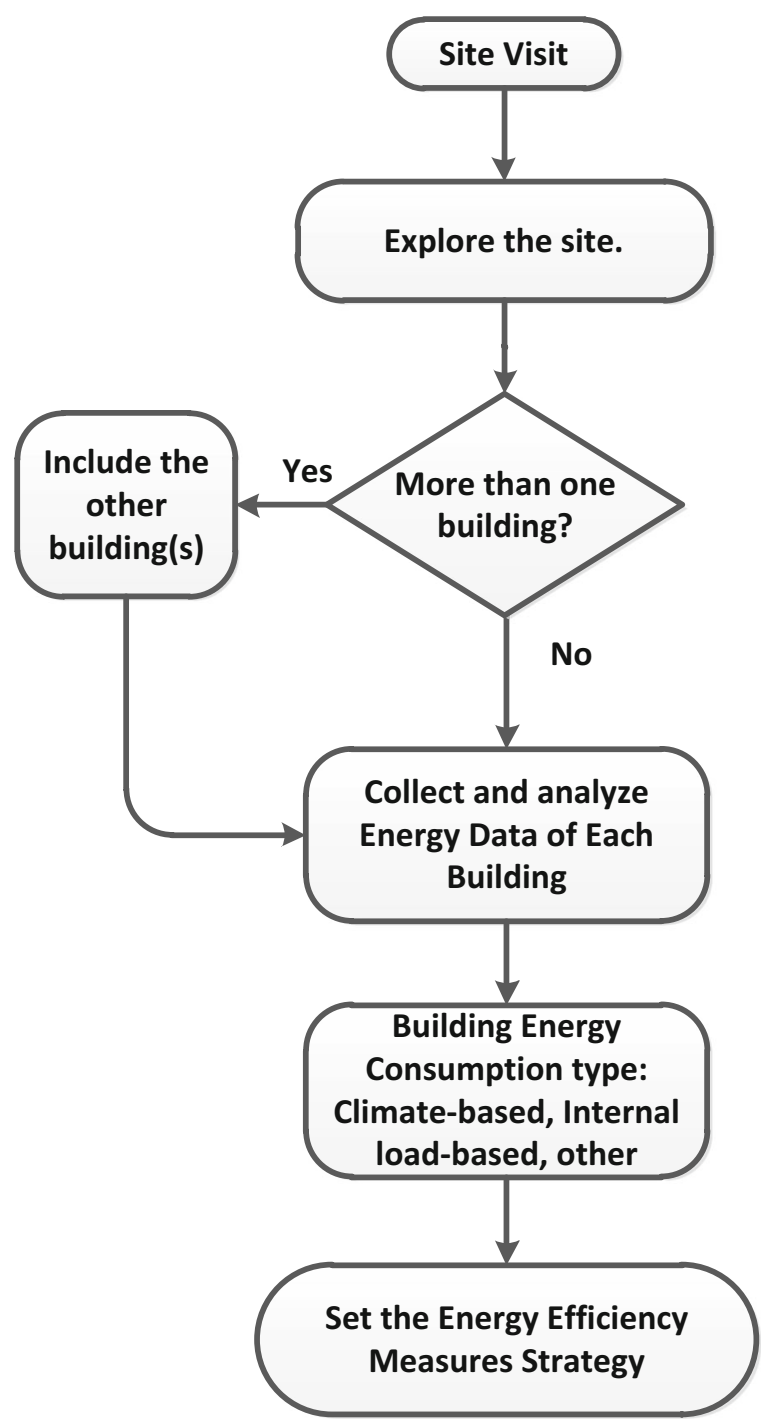

Fig. 1 Flowchart of the macro-scale assessment level 
of the main challenges of assessing an existing building's energy performance is the available energy data of the building. In most situations, the building has only one main energy meter which makes it difficult to segregate the energy components and their share on the consumption of the studied building. For this reason, energy meters are installed to measure the system and/or internal load of a typical zone(s) over the real living operating conditions in not less than two weeks. Such a technique will pave the way for creating and validating a building model, which will be a reliable tool to evaluate the recommended energy efficiency measures (EESs). This micro-scale method is demonstrated in Fig. 2 and implemented in the studied building (case study); see section "Measuring cubical plug loads" to section "Macro/ micro-scales of buildings' energy consumptions analysis."

\section{Descriptions of building and HVAC}

Building's description

The building under study, "Metro Building," is a regional government office building, located at $45.5^{\circ} \mathrm{N}$ latitude and $122.7^{\circ} \mathrm{W}$ longitude in Portland, OR. The building was originally built in the 1940s for Sears and was later remodeled in 1992. Metro Building is a sevenstory office building oriented north-south (see Fig. 3). It consists of office spaces, conference rooms, Metro government council chambers, a daycare, and parking facilities (enclosed and attached). The fourth floor of the building houses the human resource department and a conference room, while both fifth and sixth floors each have a conference room. The Metro main building houses roughly 400 employees with around $8725.6 \mathrm{~m}^{2}$ of occupied space. There are two parking facilities on the building site; one is enclosed while the other is attached. The enclosed parking is in the basement and first level with a total of $3335.7 \mathrm{~m}^{2}$ of floor area, while the attached parking has four levels consisting of a 4155.0- $\mathrm{m}^{2}$ floor area.

The building is made of concrete and brick construction and has a flat roof. The roof is covered with a river rock and is insulated with $20-25 \mathrm{~cm}(8-10 \mathrm{in}$.) of foam block insulation. It is unknown if the walls are insulated; therefore, the exact overall heat transfer ( $U$-value) is calculated based on no insulation. The windows are

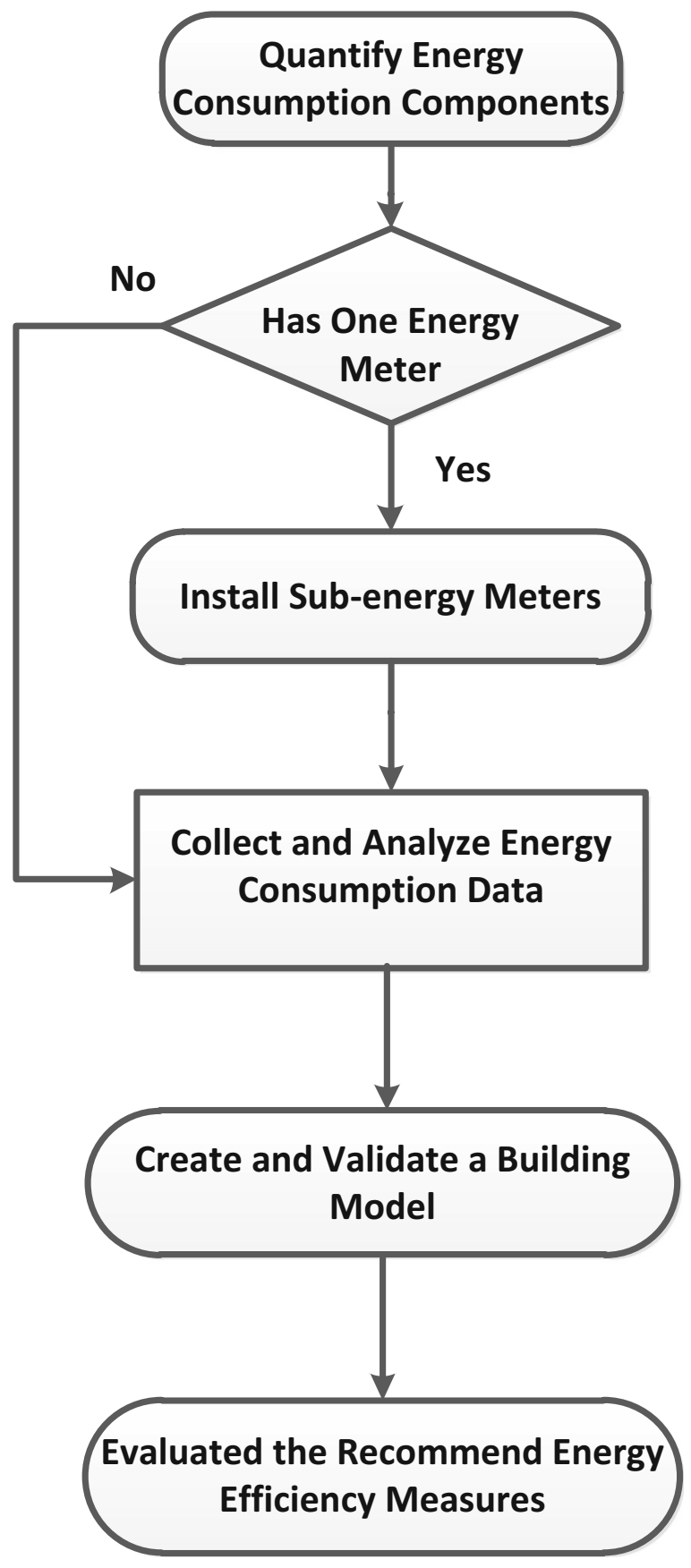

Fig. 2 Process of an energy audit of an existing building

double-paned, metal framed with thermal breaks. The windows are tinted grayish/blue. The skylights run down the center section of the building and are double low-E type. Based on the available information, the overall heat transfer ( $U$-value) of the wall, roof, windows, and skylight was taken to be $0.528,0.283,2.665$, and $1.761 \mathrm{~W} / \mathrm{m}^{2} . \mathrm{K}$, respectively. 
Fig. 3 Metro building main entrance view (left). Model created by simulation program (right)

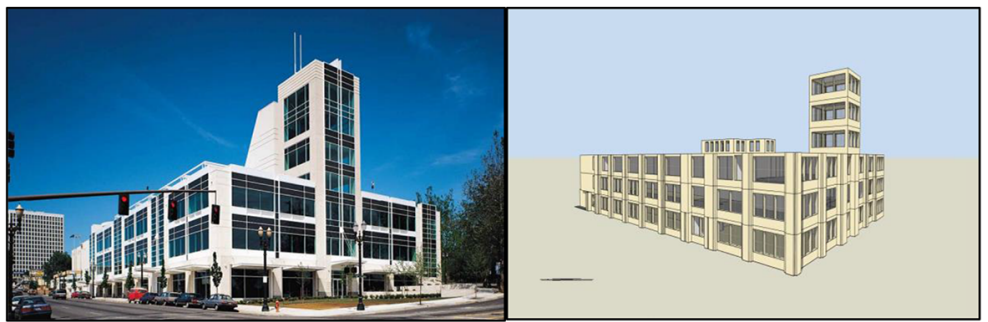

HAVC system and boiler specifications

\section{Boilers}

Hot water is provided for the main building by a condensing gas water heater (227 1, 96\% efficiency). The daycare and kitchen are served by a different boiler, a gas water heater (378 1,80\% efficiency). The daycare and kitchen water heater is set at $\sim 56{ }^{\circ} \mathrm{C}$ to serve the kitchen and has a mixing valve to lower the temperature to other faucets $\left(\sim 53^{\circ} \mathrm{C}\right)$. Currently, the mixing valve is set to deliver water to non-kitchen areas as well. Both water heaters have a hot water recirculation pump that runs constantly.

\section{Rooftop system}

Heating and cooling loads are supplied by four rooftopmounted gas packs, installed in 1992. The four units are installed with supply air temperature reset capabilities. The two larger units use gas heater warm-up in the morning only, while the two smaller units use gas heat at all times. The two larger units are served by a variable air volume (VAV) distribution system that has multiple fan-powered boxes with electric reheat for the perimeter zones and with variable volume boxes for the interior zones. The larger units have a sensible heating/cooling capacity of $472 / 259.4 \mathrm{~kW}$ and $254 / 231.5 \mathrm{~kW}$, which is distributed by supply/return fans $56 / 30 \mathrm{~kW}$ and $30 /$ $18.6 \mathrm{~kW}$. The two smaller units have constant air volume (CAV) with a sensible heating/cooling capacity of 93.8/78.8 and 62.7/58.6; both have supply/return fans 5.6/2.2 $\mathrm{kW}$. The building has 33 fan-powered boxes with $37 \mathrm{VAV}$ boxes for the distribution system.

\section{Miscellaneous}

In addition to the above-described HVAC system, there are a few other systems, including two split-system airconditioning units serving a server room on the second floor of the building. Also, there are multiple constantspeed exhaust fans for the restrooms, a constant-speed kitchen exhaust fan for the daycare center, and multiple exhaust fans on timers for the parking garage. And there are also pressurization fans for the stairs, elevators, and equipment room. These miscellaneous systems make up a total capacity of $68.8 \mathrm{~kW}$.

\section{Lighting and equipment}

The building uses mainly T-8 fluorescent lamps on a fixture of 3 lamps with the capability of operating 2 lamps only. There is no existing control associated with the lighting circuits. The building is mainly utilized for office-related activities, and most of the floor space is made of cubicles. The equipment used in those offices comprises personal computers with two flat screens and a task light, and some offices have extra equipment such as speakers.

\section{Building energy performance analysis}

The building energy management constantly aspires to improve building energy performance. In 2011, an energy audit team provided energy conservation measures, which led to a reduction in building energy consumption. Fortunately, this positive experience became the catalyst for the building's energy management to contemplate leaping towards a net-zero energy building (NZEB).

\section{Annual load}

In the assessment of a building, any major changes such as building renovation and EESs implementation to improve building performance play an important role in the level of building energy consumption. Therefore, in this study, changes in building performance before and after the previously implemented energy 
conservation measures have been considered as the turning point in building energy performance. In the year 2011, the decision-makers of the building assigned an energy company to conduct a preliminary energy audit. The recommended energy conservation measures were implemented; these involved controlling the HVAC system supply and setback temperatures. It can be seen clearly in Fig. 4 with the measured data for the years 2012-2014 that an improvement in energy consumption has been achieved. In particular, electricity has been reduced by approximately $20 \%$, even though gas consumption did not show any reduction. It is worth mentioning that the gas represents a small fraction of the total energy demand, only about $8 \%$.

\section{Monthly load}

Looking at the measured monthly energy consumptions always gives a different perspective on building energy performance. Portland, OR, is considered a mild climate zone $\left(4{ }^{\circ} \mathrm{C}\right.$ as per ASHRAE classification) with more heating degree-days $(3154 \mathrm{~h})$ at a base temperature of $16{ }^{\circ} \mathrm{C}$ than cooling degree-days $(355 \mathrm{~h})$ at a base temperature of $\sim 18{ }^{\circ} \mathrm{C}$. A monthly average measured electricity and gas consumptions based on several years (2012-2014) of the new situation, after the implemented energy conservation, have been calculated; see Fig. 5. There was a logical trend of the heating demand, where it was reduced in the summer months and increased in the winter months. While the electricity consumption did not show a similar trend, it did, however, show a baseload throughout the year with an increase of 20 $27 \%$ on some particular months, namely May, July, August, and December. This is a clear indication that the main electrical energy consumption of the building was not influenced significantly by outside conditions, but rather depended on the internal load that primarily influenced energy consumption.

\section{Measuring cubical plug loads}

The plug loads play a major role in the building's overall energy consumption. Separate power meters were used to monitor the plug loads of typical offices in the studied building over the actual operational conditions. Three different types of offices were under investigation since they differ on their setup due to individual thermal comfort. The setup of equipment used within the cubical

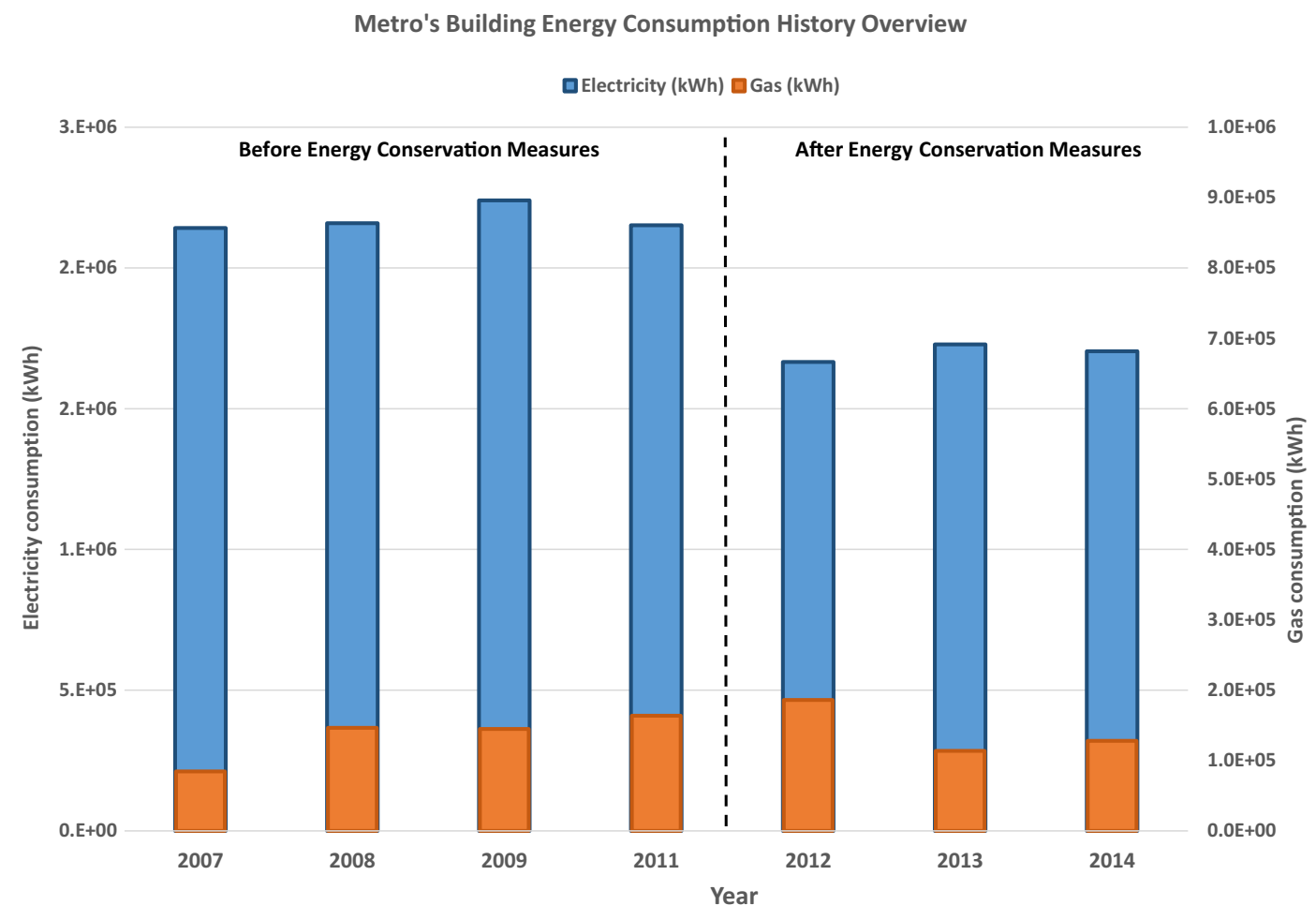

Fig. 4 Building's energy consumption history 


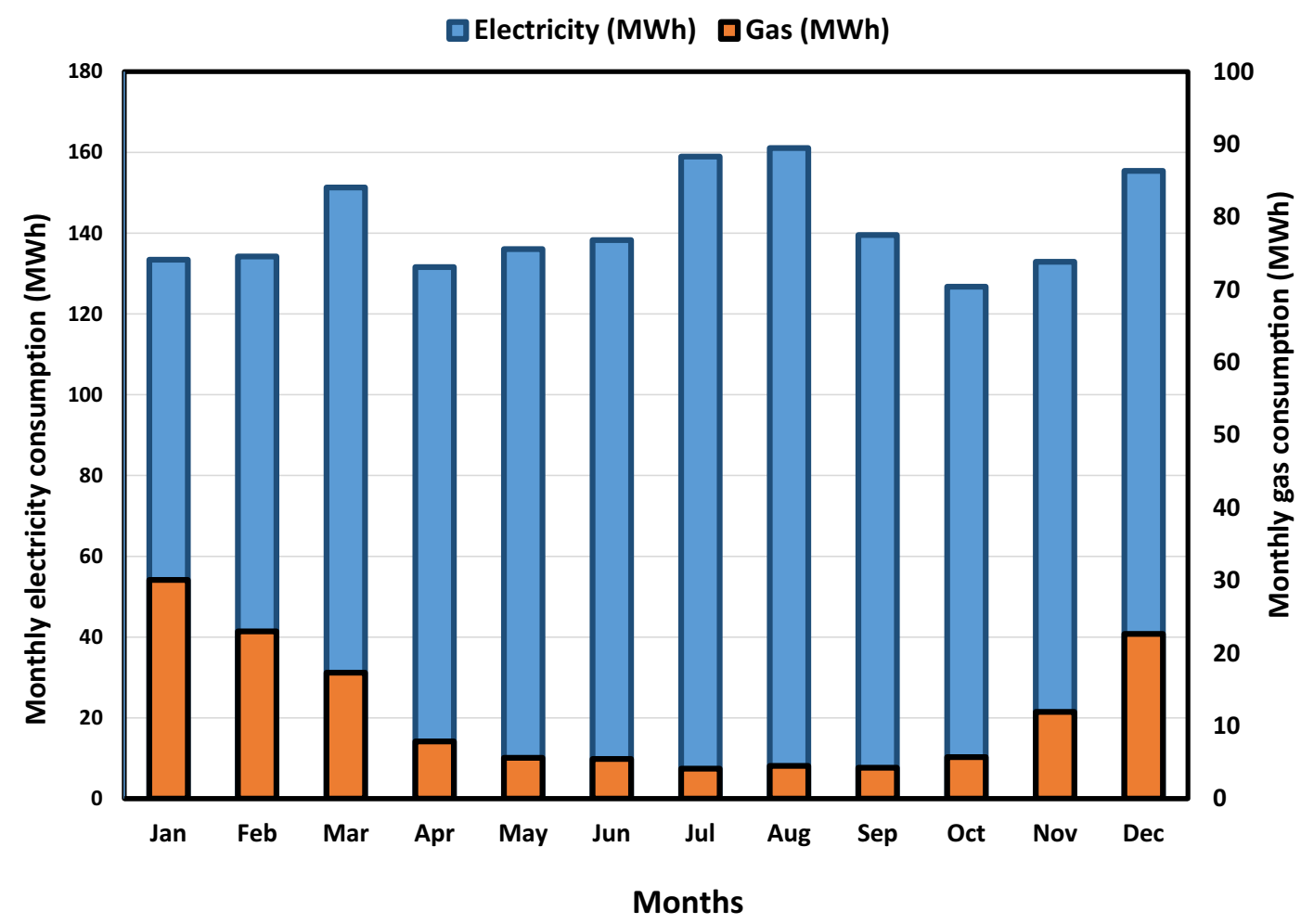

Fig. 5 Monthly consumption of the building (electricity and gas)

offices can be classified into one of three categories: (1) most common, (2) less likely, and (3) rarely. The "most common" category includes one desktop computer, two flat-screen monitors, and a task light. The "less likely" category includes an additional task light. The "rarely" category includes, in addition to the "less likely", a speaker, an electrical heater, and Christmas tree lights.
Three offices that represent three different categories were monitored over one week (see Table 1); the offices' average occupancy density was $10 \mathrm{~m}^{2}$ per person. This data revealed the amount of energy consumed and the power intensity of the equipment. In Table 1 , the annual energy consumption and power intensity are projected based on the measured week. This

Table 1 Energy consumption measurement of three different cubical setups

\begin{tabular}{ccc|ccc|ccc}
\hline $\begin{array}{c}\text { Week } \\
(\mathrm{kWh})\end{array}$ & $\begin{array}{c}\text { Annual } \\
(\mathrm{kWh})\end{array}$ & $\begin{array}{c}\text { Intensity } \\
\left(\mathrm{W} / \mathrm{m}^{2}\right)\end{array}$ & $\begin{array}{c}\text { Week } \\
(\mathrm{kWh})\end{array}$ & $\begin{array}{c}\text { Annual } \\
(\mathrm{kWh})\end{array}$ & $\begin{array}{c}\text { Intensity } \\
\left(\mathrm{W} / \mathrm{m}^{2}\right)\end{array}$ & $\begin{array}{c}\text { Week } \\
(\mathrm{kWh})\end{array}$ & $\begin{array}{c}\text { Annual } \\
(\mathrm{kWh})\end{array}$ & $\begin{array}{c}\text { Intensity } \\
\left(\mathrm{W} / \mathrm{m}^{2}\right)\end{array}$ \\
\hline 12.5 & 600 & 50 & $\begin{array}{c}15.5 \\
\text { Standard cubical office }\end{array}$ & $\begin{array}{l}\text { Cubical office with the extra light } \\
\text { task }\end{array}$ & $\begin{array}{l}\text { Cubical } \\
\text { additional plug load }\end{array}$ \\
\hline
\end{tabular}


measurement proved that the plug load consumption and intensity of the studied cubical offices were far more than the benchmark values (Menezes et al. 2014).

Energy use intensity

The energy use intensity (EUI) is an index to evaluate the overall building energy performance; it measures the building energy consumption divided over its total floor area. This index can indicate how the building behaves in terms of its counterparts with similar activity and climate. The EUI of the studied building (Metro) has been calculated before and after implementing the energy conservation measures. It has also been compared to the published Department of Energy (DOE) benchmark (DOE, Office of Energy Efficiency, and Renewable Energy n.d.) as well as regional benchmark buildings (see Fig. 6). This comparison reveals that the building has an opportunity for further reduction in consumption. Also, some particular components of the building (heating and cooling) show a higher consumption than comparable buildings in the region by $\sim 20 \%$ using the validated model breakdown versus the Energy Data Book (DOE, Office of Energy Efficiency, and Renewable Energy n.d.).
Calibrating the building model

To calculate the building's energy consumption components such as HVAC, plug loads, and lighting, a building dynamic simulation program (DesignBuilder V5.0) is used. The building model was created to calibrate and subsequently to evaluate the proposed energy efficiency strategies (EESs); see the right side of Fig. 3. The model included the building layout (geometry and orientation), construction (envelope and skylight specifications), lighting, equipment and HVAC systems, interior floors' layouts, occupants' working schedules, and local weather files.

The model was calibrated against the total monthly electricity and gas consumption over the years (20122014). The building model was tweaked until acceptable agreements between electricity and gas consumption were reached; see Table 2. This is one of the most critical steps for calibrating an existing building; many variables need to be tuned based on on-site visits, system documentation, and facilities staff's feedback. These variables were mainly the plug loads, lighting intensities and their schedules, the indoor temperature set points for both the cooling and heating of $22^{\circ} \mathrm{C}$ and $21{ }^{\circ} \mathrm{C}$, respectively (these were taken from actual

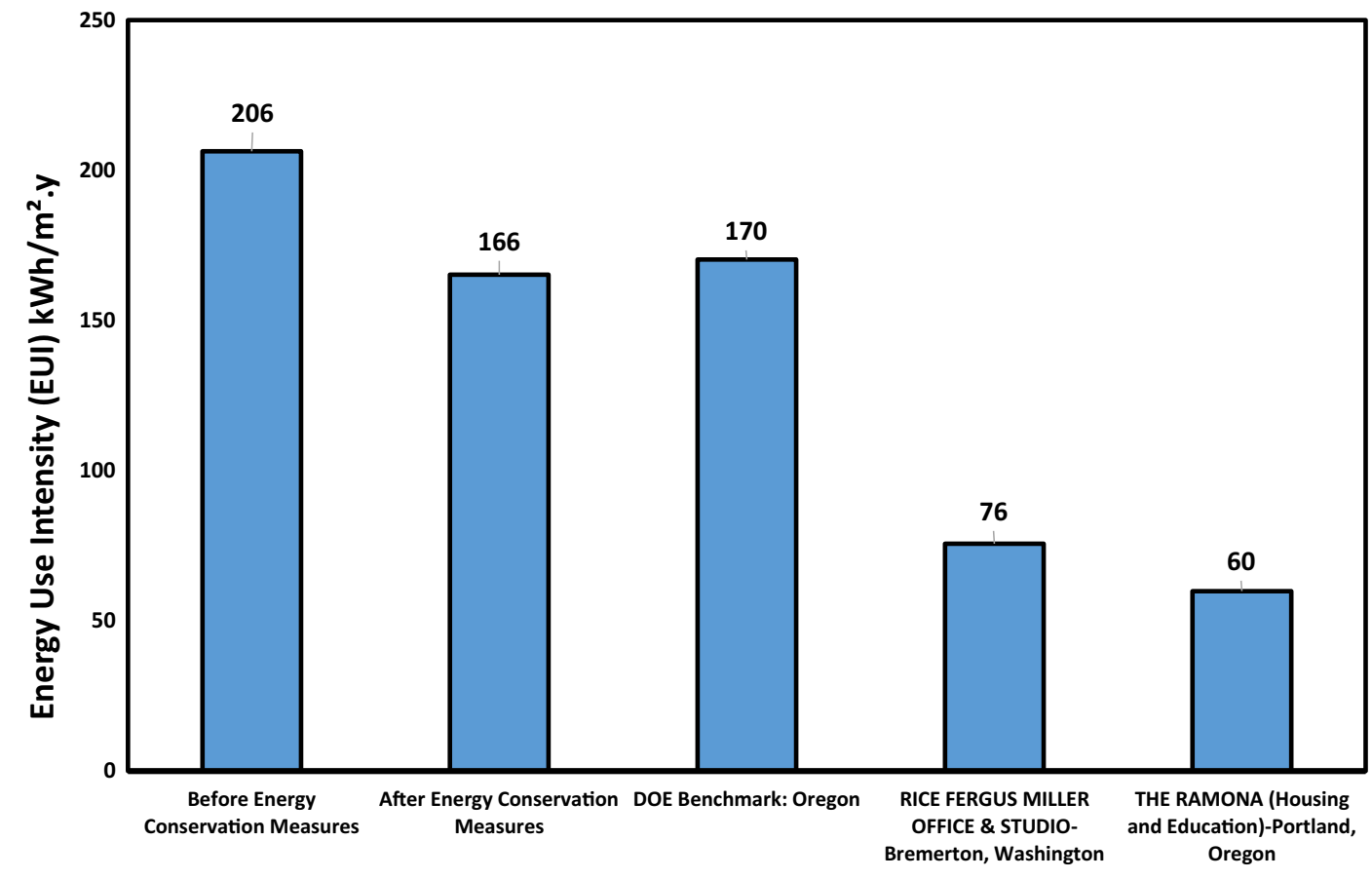

Fig. 6 EUI of Metro's main office building compared with other references 
Table 2 Validated results of the building simulated model

\begin{tabular}{|c|c|c|c|c|c|c|}
\hline & \multicolumn{2}{|c|}{ Measured } & \multicolumn{2}{|c|}{ Simulated } & \multicolumn{2}{|l|}{ MBE } \\
\hline & $\begin{array}{l}\text { Elect. } \\
\text { MWh }\end{array}$ & $\begin{array}{l}\text { Gas } \\
\text { MWh }\end{array}$ & $\begin{array}{l}\text { Elect. } \\
\text { MWh }\end{array}$ & $\begin{array}{l}\text { Gas } \\
\text { MWh }\end{array}$ & $\begin{array}{l}\text { Elect. } \\
\%\end{array}$ & $\begin{array}{l}\text { Gas } \\
\%\end{array}$ \\
\hline Jan & 133.40 & 30.09 & 137.94 & 29.89 & -3.4 & 0.7 \\
\hline Feb & 134.20 & 22.99 & 133.78 & 23.69 & 0.3 & -3.0 \\
\hline Mar & 151.30 & 17.32 & 155.18 & 17.95 & -2.5 & -3.7 \\
\hline Apr & 131.60 & 7.87 & 129.39 & 7.79 & 1.7 & 1.1 \\
\hline May & 136.10 & 5.62 & 134.75 & 5.58 & 1.0 & 0.6 \\
\hline Jun & 138.20 & 5.47 & 134.44 & 5.33 & 2.8 & 2.6 \\
\hline Jul & 159.00 & 4.11 & 155.10 & 4.22 & 2.4 & -2.7 \\
\hline Aug & 161.10 & 4.49 & 154.92 & 4.51 & 3.8 & -0.5 \\
\hline Sep & 139.50 & 4.26 & 135.90 & 4.12 & 2.6 & 3.2 \\
\hline Oct & 126.80 & 5.71 & 127.34 & 5.55 & -0.5 & 2.8 \\
\hline Nov & 132.90 & 11.94 & 134.03 & 11.96 & -0.9 & -0.1 \\
\hline Dec & 155.40 & 22.66 & 155.55 & 22.62 & -0.1 & 0.2 \\
\hline Annual & 1699.50 & 142.53 & 1688.31 & 143.21 & 0.7 & -0.5 \\
\hline
\end{tabular}

measurements), and the mechanical systems' performance and their schedules of operation. The occupants' presence was set from 8:00 to 18:00 Monday to Friday. In Table 2, the mean bias errors (MBEs) between the calibrated model (simulation) energy and the measured consumption of electricity and gas are presented. The MBEs of the monthly and annual gas and electricity consumptions are found to be lower than the acceptable value of $5 \%$ recommended by the ASHRAE Standard14 (ASHRAE 2002).

Macro/micro-scales of buildings' energy consumption analysis

Since the model is calibrated, the building energy consumption can be analyzed using a building simulation program (BSP), which in this study is the DesignBuilder at macro- and micro-scales. In this study, the building has many different sections comprising the main building, two parkings, and a daycare center. There are two parking structures; one is enclosed within the main building (basement and first level), while a large parking garage (four floors) is attached to the main building. The daycare center is also connected to the first level on the northeast side of the building.

From a macro-scale perspective of the site's energyconsuming components, the main building consumes $78 \%$ while the enclosed daycare center and two attached car parks consume $8 \%, 6 \%$, and $8 \%$, respectively; see Fig. 7. This would assist the energy auditor with the initial analysis by comparing the correct EUI for each building's sector. In this study, the main building has only been compared to a similar building activity benchmark. However, the energy efficiency strategies that have been conducted in the main building and daycare center are different from those performed for the carparks. The only EES conducted on the carparks was the efficient lighting strategy. It is worth noting that many energy assessors may pay less attention to the parking garages, even though they might have significant opportunities for energy saving on such facilities.

On a micro-scale, the main building indicates that the internal load (computers and monitors, lighting, and office equipment) compromises about $50 \%$ of its consumption; see Fig. 8. On the other hand, electrical heating and cooling including distribution systems, domestic hot water (DHW), gas heating, pumps, and auxiliary consumption are $25 \%, 11 \%, 8 \%, 6 \%$, and $1 \%$, respectively.

\section{Towards net-zero energy building (NZEb)}

The ultimate goal of Metro sustainability management is to convert its main building into a net-zero energy building (NZEB). As stated earlier in terms of NZEB definitions, the objective is to minimize the building

\section{$\square$ Main Building $\square$ Enclosed CarPark $\square$ DayCare $\square$ Attached CarPark}

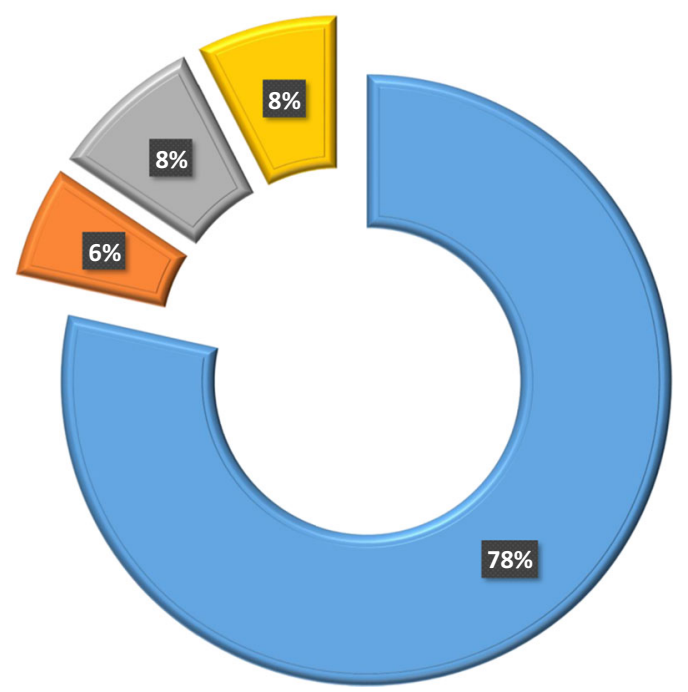

Fig. 7 Energy consumption distribution of the Metro site 


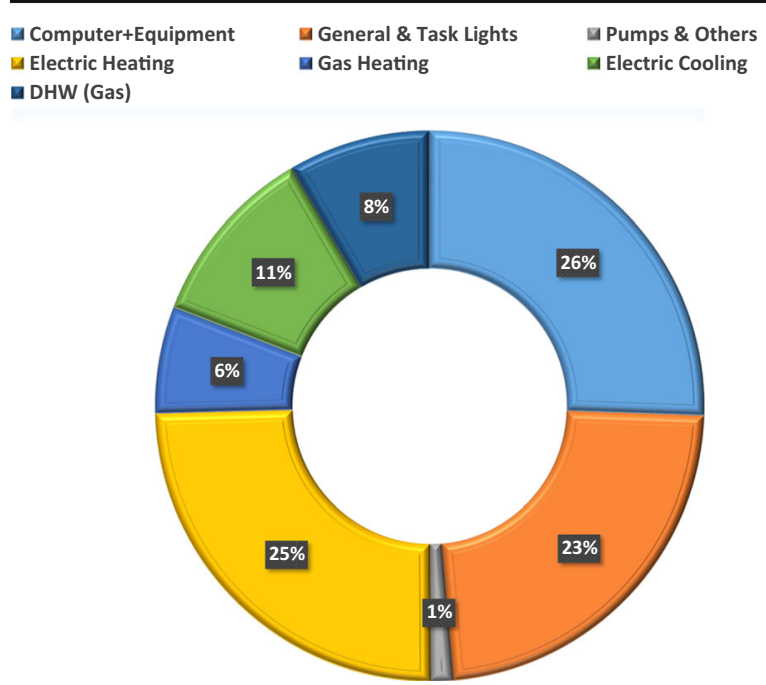

Fig. 8 Main Metro building energy consumption components

consumption and cover the remaining demand from renewable sources throughout the year. The first step towards this ambitious goal is to minimize the building EUI to its lowest possible value by implementing feasible energy efficiency strategies (EESs). Then, renewable energy options will be considered to overcome the remaining building demands. Before selecting possible EESs, it is logical to start with the geographical influences on the building, i.e., the building's climate. It is worth noting that the energy efficiency strategies with technical difficulty in terms of implementation and high disturbance to the occupants have been excluded. For instance, increasing the insulation of the roof and walls and improving fenestration properties are not included; in addition, the initial assessment showed that a smaller amount of energy consumption can be saved.

\section{Climate consideration}

The building's climate zone or even the microclimate can effectively be a guide to the feasibility study of the project. In this study, the Climate Consultant software is used to provide basic design suggestions for effective energy efficiency measures (EESs). The program came with 20 strategies that would make the building more efficient. Although most of these strategies are intended for new building designs, many strategies have been found to be worth evaluating in this study such as the following: (1) efficient window (double low-E), (2) sealing the building envelope to reduce infiltration and obtain benefit from the internal load so as to reduce the demand on the heating system, (3) lowering the indoor comfort temperature at night so as to reduce heating energy consumption, (4) high-efficiency heaters and/or boiler, (5) insulated blind, heavy draperies or operable window shutter automatically controlled.

\section{Efficient plug loads}

The building energy performance analysis shows that plug loads in the office accounted for approximately $50 \%$ of the main building's energy consumption (Fig. 6). Improvements in office equipment efficiency in the past several years allowed for a dramatic reduction in power demands, from $250 \mathrm{~W}$ for a desktop and two monitors $(56 \mathrm{~cm})$ to $90 \mathrm{~W}$ for a laptop of similar monitor size. Therefore, the first recommendation is to upgrade their computer setup with those who require less energy $(90 \mathrm{~W})$. Thus, the power density of the computer and equipment is reduced from 60 to $20 \mathrm{~W} / \mathrm{m}^{2}$. The predicted annual energy savings of this energy-efficient strategy will be $277.3 \mathrm{MWh}$. Interestingly, this will make it possible to bring down the building EUI from 165 to $134 \mathrm{kWh} / \mathrm{m}^{2}$.year.

\section{Efficient windows and shading}

One of the first strategies that might confront an energy assessor is to retrofit the window system, i.e., the window type and its attachment such as overhang, fins, and interior blind. The model was tried with different shading strategies such as using louvers or overhangs. Unfortunately, none of these strategies showed a significant improvement in the building energy consumption since the energy saved by adding shading to reduce the cooling load would be paid off using more of the heating system due to the shading effect. This unimproved situation due to the south façade which is the main influential orientation of the solar heat gain has the least window to wall ratio.

The evaluated efficient window of the double-pane low-E (external of the exterior layer and $6 \mathrm{~mm}$ clear of the interior) with the UPVC frame also showed an insignificant saving (17.50 MWh annually); this is considered to be an infeasible EES. Avoiding these options will also reduce the level of unwanted distribution among the building's users. 
Building tightness and ventilation control

Commercial buildings tend to have a high rate of air change per hour $(\mathrm{ACH}, 3-5)$ due to infiltration and ventilation, and this is particularly true for buildings built several decades ago. Metro has various air changes per hour throughout the year due to variations in wind speed and direction for each month. In this building, a different air change per hour has been allocated to each building's level as a final variable input during the validating process.

A reduction in infiltration and mechanical ventilation can occur by sealing all leaks around the windows and doors, with a particular emphasis on reducing infiltration along the northwest and east sides of the building. Additionally, the installation of a demand control ventilation (DCV) for the meeting rooms will reduce the load from mechanical ventilation use. After these two modifications had been made, the total air change per hour was reduced from 3.0 to 2.0. This strategy will save 218.14 MWh annually; see Fig. 7. A further reduction by this strategy will be able to bring the building's EUI to $109 \mathrm{kWh} / \mathrm{m}^{2}$.year.

\section{Efficient lighting system}

The majority of the lighting system in the building were changed to LED instead of the existing fluorescent lamp, T8 type. The LED demands $8 \mathrm{~W}$ type while the T8 used a type that demanded around $19.5 \mathrm{~W}$. Thus, the total lighting power density (LPD) will be reduced from approximately 14 to $6 \mathrm{~W} / \mathrm{m}^{2}$.

Therefore, the building is predicted to be able to reduce the main building's energy use to 209.41 MWh annually. Also, the two parking facilities' energy consumption will be dramatically reduced to $78.0 \mathrm{MWh}$ annually, which represents only $31.6 \%$ of its current consumption. The lighting control has been set mainly in the offices on the second and third floors. With such energy-efficient strategies, the EUI can be reduced to $85 \mathrm{kWh} / \mathrm{m}^{2}$ annually, which is very encouraging in terms of achieving NZEB.

\section{Efficient HVAC and boilers}

The final leg of the NZEB was to upgrade the heating, ventilating, and air-conditioning to a better energyefficient system. A variable refrigerant flow (VRF) system, with heat recovery, dedicated outside air system
(DOAS), and economizer based on differential dry-bulb temperatures, was proposed as a replacement for the current system. The validated coefficient of performance (COP) for the existing HVAC system showed an average of $\sim 1.7$. The lower value of the COP is due to degradation in the system and using gas as fuel for heating. Instead, the proposed new system will serve the building with an average of $\sim 3.5$ COP. A total of $148.33 \mathrm{MWh}$ was the predicted savings. Upgrading the HVAC system will reduce the building EUI to $66 \mathrm{kWh} / \mathrm{m}^{2}$.year.

On the other hand, upgrading the larger boiler with better performance did not show any significant improvement compared to the installed efficiency (80\%). The gas consumption only represents $8.5 \%$ of the total existing consumption.

Implementing the most effective EESs will bring down the current building energy use intensity (EUI) from 166 to $66 \mathrm{kWh} / \mathrm{m}^{2}$.year; see Fig. 9.

\section{Integrating renewable energy}

From the above discussion, the energy intensity (EUI) of the building after renovation will be $66 \mathrm{kWh} / \mathrm{m}^{2}$.year. Renewable energy will then cover the remaining building energy demand. In this study, PVs will be analyzed on an annual basis from site and primary source energies' perspectives. This concept utilizes the recent redefinition of a net-zero energy building (NZEB) by the Department of Energy (DOE) to include not only the building site demand but also the primary source of energy for the building. Since the primary source of energy for the annual electricity production of the State of Oregon is mainly hydroelectric $(3200 \mathrm{GWh})$ and renewable $(600 \mathrm{GWh})$, with the remaining demand covered by natural gas-fired $(1700 \mathrm{GWh})$ and coal-fired (300 GWh), achieving NZEB on the basis of site will automatically comprise the primary source of energy. In this section, an explanation on how to implement the renewable energy concept so as to achieve the NZEB concept is applied to the studied building (Metro) site.

The energy that can be produced from the photovoltaic panels (PVs) is affected by factors such as orientation, shading, self-shading, and collector efficiency. After considering all these factors, the tested PVs (direct current with $90 \%$ efficiency inverter) can still produce a significant amount of energy. The photovoltaic (PV) panels of crystalline silicon with approximately $\approx 17.5 \%$ efficiency as well as a generator efficiency design-specific 


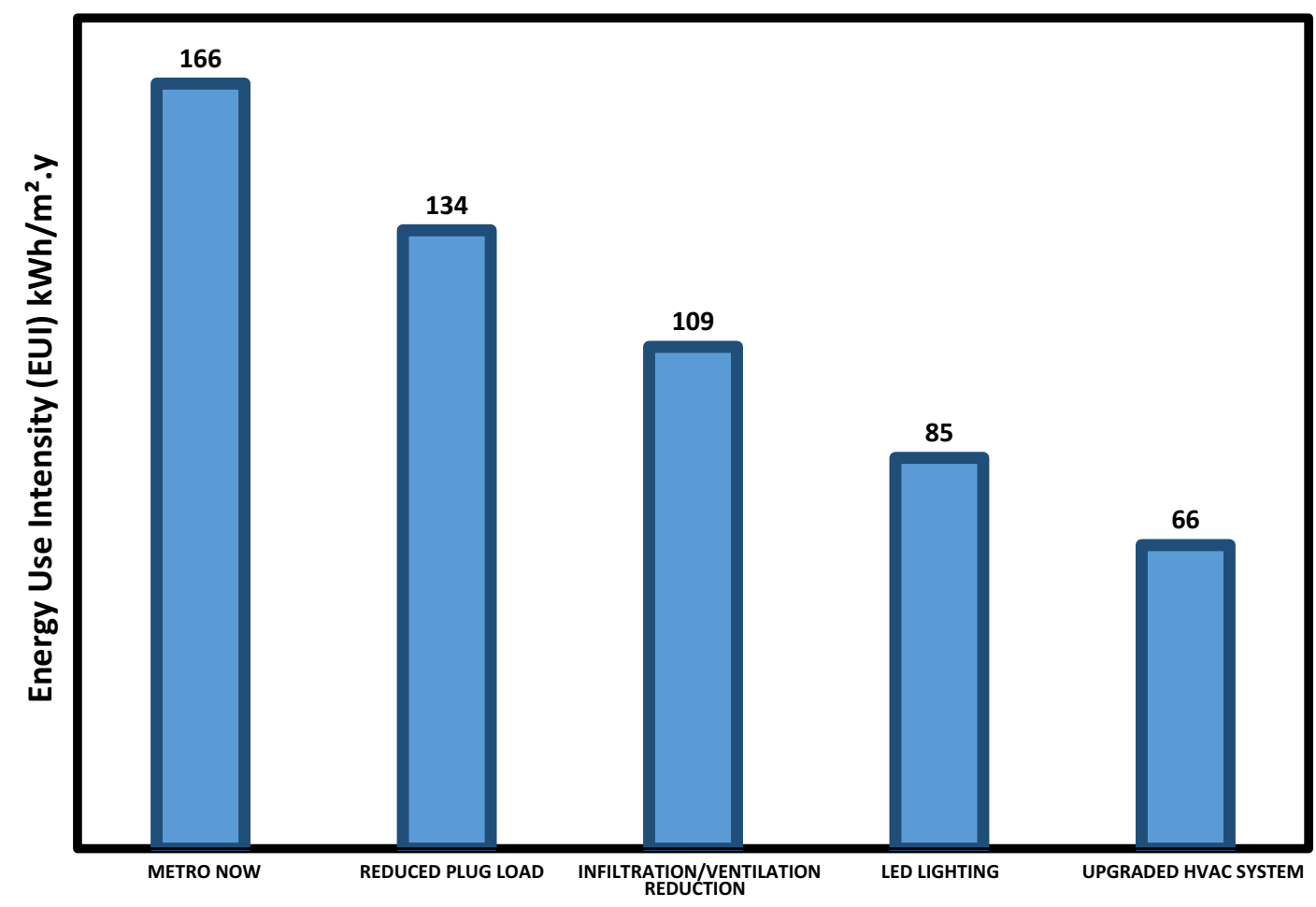

Fig. 9 EUI progress after implementing each EES

conversion made a global system efficiency of $14.5 \%$. The $\mathrm{PV}$ technology is very promising, so a higher efficiency is predicted to be available in the market sooner rather than later.

The annual PV panels' production on the roofs of the main building $\left(2066 \mathrm{~m}^{2}\right)$ and the attached parking $\left(3418 \mathrm{~m}^{2}\right)$ is 303 and $532 \mathrm{MWh}$, respectively. The total building energy demand after implementing EES will be 490.5 MWh, and therefore, utilizing the parking roof alone will be sufficient to convert the building to NZEB. The variation between the monthly production and demand is shown in Fig. 10. In a trial to cover the peak demand in the winter months (October to March), some wind turbines have been evaluated; this scenario can

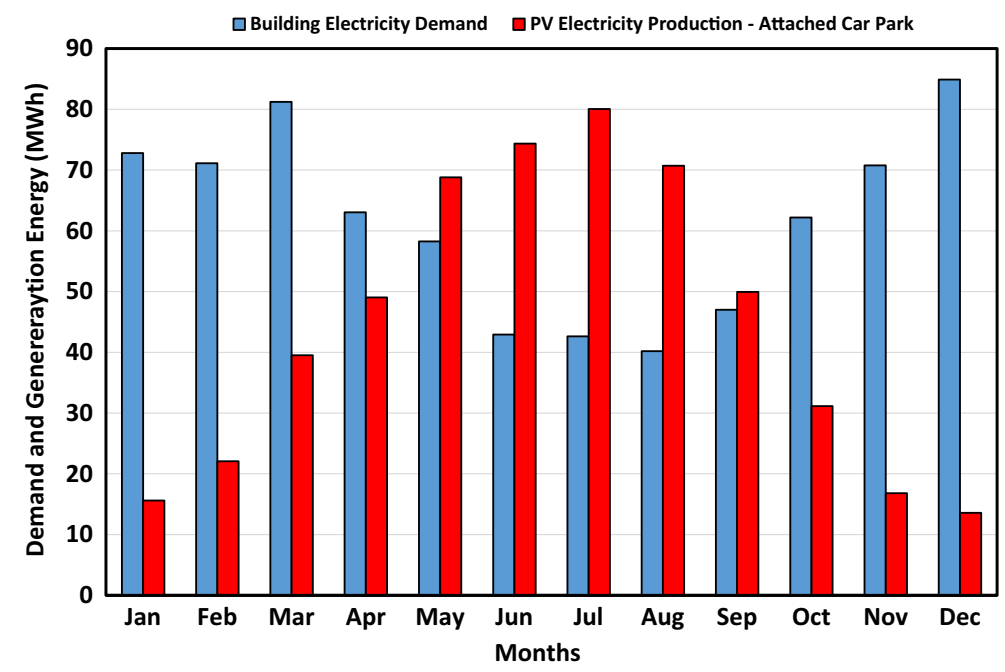

Fig. 10 Monthly building demand PV production energy 
produce insignificant power production of $115 \mathrm{MWh}$ annually though not on the peak months.

\section{Cost and environmental analysis}

Many greenhouse gasses contribute to environmental pollution. $\mathrm{CO}_{2}$ is the main contributor to global warming, and for this reason, only $\mathrm{CO}_{2}$ emissions are considered in the present work. As such, the environmental impact of EESs is determined by the amount of prevented $\mathrm{CO}_{2}$ emissions when EESs are implemented. Similarly, prevented $\mathrm{CO}_{2}$ emissions for solar energy systems assume that each kilowatt-hour generated by a solar system is a substitute for each kilowatt-hour produced by the conventional energy systems. In this study, the estimated prevented $\mathrm{CO}_{2}$ emission is based on a plant emission factor (Portland, Oregon) of $1.215 \times$ $10^{-4}$ metric tons $\mathrm{CO}_{2} / \mathrm{kWhe}$ (EPA United States Environmental Protection Agency 2013).

On the other hand, the feasibility of various EESs in being able to reduce the existing building energy consumption is evaluated using the simple payback period (SPP). This is obtained by dividing the capital cost of the measure by the cost of the annual energy savings. The amount of money saved annually is calculated by multiplying the actual tariff in Portland, OR $(0.0879$ \$/kWh) by the amount of energy savings (EPA United States Environmental Protection Agency 2013).

The overall benefit of solar systems over conventional electricity sources can be demonstrated by calculating the energy payback period. The system's energy payback is the time (in years) in which the energy input during the system's lifespan is compensated by the energy generated using a renewable energy system. The energy payback time depends on several factors, including solar system technology, application, and solar insolation.

To include the cost of each energy efficiency measure over its life expectancy, a complete life cycle cost analysis is discussed. To calculate the life cycle cost (LCC), the initial (investment) cost (IC) for each implemented energy efficiency measure and the annual energy cost (EC) are obtained based on the simulation results. In addition, the uniform series present worth (USPW) factor is used to convert all the annual energy costs to the present; the relationship between these variables is defined by Eq. (1):

$\mathrm{LCC}=\mathrm{IC}+\left[\operatorname{UPSW}\left(N, r_{d}\right) \times \mathrm{EC}\right]$

USPW is a function of both the lifetime $(N)$ of the system and the discount rate $\left(r_{d}\right)$ of the economy, as stated by Eq. (2):

$\operatorname{USPW}\left(N, r_{d}\right)=\left[1-\left(1+r_{d}\right)^{-N}\right] / r_{d}$

Throughout this analysis, lifetime is dependent on the evaluated element. Therefore, it ranges from 5 to 30 years. The annual discount rate is set at $5 \%$. A life cycle cost analysis of all considered technologies is presented in Table 3. As shown in that table, all energy efficiency measures show a better value over their life cycle.

Several energy efficiency strategies (EESs) are considered to convert the building to an NZEB. First, reducing the plug loads will save 277.3 MWh on an annual basis (16.4\%), which also protects the environment from 33.7 tons of $\mathrm{CO}_{2}$ emission. This strategy was calculated based on the assumption that 400 employees

Table 3 Cost and environmental analysis of the implemented EEMs

\begin{tabular}{|c|c|c|c|c|c|c|c|}
\hline $\begin{array}{l}\text { Energy efficiency } \\
\text { strategies (EESs) }\end{array}$ & $\begin{array}{l}\text { Energy saved } \\
\text { (MWh/year) }\end{array}$ & $\begin{array}{l}\text { Percentage of } \\
\text { saving } \\
(\%)\end{array}$ & $\begin{array}{l}\mathrm{CO}_{2} \text { saved } \\
\text { (metric tons/year) }\end{array}$ & $\begin{array}{l}\text { Payback } \\
\text { period } \\
\text { (years) }\end{array}$ & $\begin{array}{l}\text { Life time } \\
\text { (years) }\end{array}$ & $\begin{array}{l}\text { Invest. } \\
\text { system cost } \\
(\$)\end{array}$ & $\begin{array}{l}\mathrm{LCC} \\
(\$)\end{array}$ \\
\hline Reduce plug loads & 277.3 & 16.4 & 33.7 & 7.4 & 5 & 147,600 & 243,657 \\
\hline $\begin{array}{l}\text { Reduce infiltration and } \\
\text { ventilation }\end{array}$ & 220.2 & 13.0 & 26.8 & 1.2 & 30 & 80,000 & 350,864 \\
\hline $\begin{array}{l}\text { Replace T8 fluorescent } \\
\text { lamp by LED }\end{array}$ & 210.2 & 12.4 & 25.5 & 4.4 & 5 & 84,000 & 282,818 \\
\hline Replace HVAC by VRF & 164.8 & 9.7 & 20.0 & 4.7 & 12 & 307,500 & 731,883 \\
\hline EES total & 872.5 & 51.5 & 106 & & & & \\
\hline Integrated PVs & 531.6 & 31.4 & 64.6 & 9.9 & 30 & 536,382 & $1,726,540$ \\
\hline
\end{tabular}

Values in italics are the result of the cost analysis 
are going to replace their computers with more efficient ones. This measure will pay back the cost in around seven years. Second, reduced infiltration and ventilation can occur by fixing the sealant around windows and exterior doors, and by implementing demand control ventilation (DCV). DCV has dropped substantially in recent years, and $\mathrm{CO}_{2}$ sensors are now priced below US\$200 (compared to over $\$ 500$ a decade ago). This energy efficiency strategy is going to save $220 \mathrm{MWh}$ annually (13\%), which prevents around 27 metric tons of $\mathrm{CO}_{2}$ emission. Interestingly, this will be paid back within a year. Other energy efficiency strategies such as replacing the lamps, replacing the HVAC, and integrating PVs will save energy by around 210 (12\%), 168 (10\%), and $532(31 \%) \mathrm{MWh}$ annually. Installation and material costs of infiltration and ventilation were obtained from RSMeans (Reed Business Information n.d.). Also, the environment will be annually protected from $\mathrm{CO}_{2}$ emissions of $25.5,20$, and 65 tons, respectively. Those energy efficiency strategies will be paid back in around 4, 5, and 10 years, respectively. These EESs are listed in Table 3.

\section{Summary and conclusion}

This work was aimed at identifying a methodology to convert conventional energy consumption buildings to net-zero energy buildings (NZEBs). Based on the validated energy model, several proposed energy efficiency strategies (EESs) and generating solar energy using photovoltaic panels were evaluated on an existing building in Portland, OR (marine climate). The economic and environmental aspects of both EESs and integrated solar energy systems were considered. The main findings of the present work are the following:

- Evaluating the building energy performance analysis must be done on both macro- and micro-scales, while refraining from doing so might lead to a misinterpretation of the energy data.

- The building simulation software is an essential tool to segregate each part of the building's site energy consumption and facilitate a fair comparison with similar building type benchmarks such as office buildings.

- Existing buildings can be converted to NZEB by implementing EESs in those buildings and integrating competent PV panels. The costs of PV panels and related equipment are expected to decrease considerably. Also, the efficiency of the PV panels is expected to improve in the coming years. These factors will shortly make PV systems more cost-effective.

- Most EESs have proven significant in saving annual energy consumption of the current building and preventing $\mathrm{CO}_{2}$ emissions. EESs are far more costeffective than integrated solar systems as the payback period for EESs varies from 1 to 7 years, whereas for PVs it is around 10 years. It is worth noting that the unselected EESs in this study are related to the building case and the climatic condition, i.e., they might well be an appropriate choice in another case.

- Implementing EESs on the studied building results in an annual energy savings of about $872.7 \mathrm{MWh}$, which is equivalent to $60 \%$ of the building consumption and prevents 106 tons of emitted $\mathrm{CO}_{2}$. While integrated PV panels generate 531.6 MWh, equivalent to $31.4 \%$ of the current consumption, they avoid 64.6 tons of emitted $\mathrm{CO}_{2}$.

- The results proved that mid-size office buildings could be converted to NZEB on a site based in the Pacific Northwest by integrating the $15 \%$ efficiency of PV panels.

- The results of the present work should encourage public authorities to convert existing mid-size office buildings to NZEB, particularly those in the Pacific Northwest.

Acknowledgments The authors would like to express their gratitude to the facility manager and staff of the Metro building for their kind cooperation. Thanks are also extended to YGH architects for sharing their expertise on coordinating with the client and providing all necessary buildings' drawings.

Abbreviations ASHRAE, American Society for Heating Refrigeration and Air-conditioning Engineers; $C O P$, coefficient of performance; DOE, Department of Energy; EESS, energy-efficient strategies; $E P B D$, EU-Energy Performance of Buildings Directive; EUI, energy use intensity; IEA, International Energy Agency; $N Z E B$, net-zero energy building; $n Z E B$, nearly zero energy building; $P V$, photovoltaic; $R E T$, renewable energy and technology; $Z E B$, zero energy building

Open Access This article is licensed under a Creative Commons Attribution 4.0 International License, which permits use, sharing, adaptation, distribution and reproduction in any medium or format, as long as you give appropriate credit to the original author(s) and the source, provide a link to the Creative Commons licence, and indicate if changes were made. The images or other third party 
material in this article are included in the article's Creative Commons licence, unless indicated otherwise in a credit line to the material. If material is not included in the article's Creative Commons licence and your intended use is not permitted by statutory regulation or exceeds the permitted use, you will need to obtain permission directly from the copyright holder. To view a copy of this licence, visit http://creativecommons.org/licenses/by/4.0/.

\section{References}

ASHRAE. (2002). ASHRAE guideline 14-2002 for measurement of energy and demand savings. Atlanta: American Society of Heating, Refrigeration and Air Conditioning Engineers.

ASHRAE. (2008). Producing Net-Zero Energy Buildings, ASHRAE Vision 2020: Providing tools by 2020 that enable the building community to produce market-viable NZEBs by 2030.

ASHRAE, ANSI/ASHRAE Standard 100-2006. (2006). Energy conservation in existing building, Atlanta: American Society of Heating. Atlanta: Refrigerating and Air-Conditioning Engineers Inc.

Belussi, L., Barozzi, B., Bellazzi, A., Danza, L., Devitofrancesco, A., Fanciulli, C., Ghellere, M., Guazzi, G., Meroni, I., Salamone, F., Scamoni, F., \& Scrosati, C. (2019). A review of performance of zero energy buildings and energy efficiency solutions. Journal of Building Engineering, 25, 100772, ISSN 2352-7102. https://doi. org/10.1016/j.jobe.2019.100772.

Cao, X., Dai, X., \& Liu, J. (2016). Building energy-consumption status worldwide and the state-of-the-art technologies for zero-energy buildings during the past decade. Energy and Buildings, 128, 198-213, ISSN 0378-7788. https://doi. org/10.1016/j.enbuild.2016.06.089.

Crawley, D., Pless, S., \& Torcellini, P. (2009). Getting to net zero. ASHRAE Journal, 2009(Sept), 18-25.

DesignBuilder Software (2016) V4.7.0.027, DesignBuilder Software Ltd (www.designbuilder.co.uk), Gloucestershire, UK. Accessed Mar 2016.

DOE, Office of Energy Efficiency \& Renewable Energy (n.d.) Building Performance Database, accessed January 2017 at https:/energy.gov/eere/buildings/building-performancedatabase.

EPA United States Environmental Protection Agency, Calculations and references; $\mathrm{CO}_{2}$ emission factor, clean energy (2013). http://www2.epa.gov/energy/ghgequivalencies-calculator-calculations-and-references. Accessed Mar 2016.

EPBD recast. (2018). Directive 2018/844/UE of the European Parliament and of Council, 30 May 2018 on the energy performance of buildings (recast); Official Journal of the European Union.

Geng, Y., Ji, W., Lin, B., Hong, J., \& Zhu, Y. (2018). Building energy performance diagnosis using energy bills and weather data. Energy and Buildings, 172, 181-191, ISSN 0378-7788. https://doi.org/10.1016/j.enbuild.2018.04.047.

Hamdy, M., Hasan, A., \& Siren, K. (2013). A multi-stage optimization method for cost-optimal and nearly-zero-energy building solutions in line with the EPBD-recast 2010. Energy and Buildings, 56, 189-203.
Hasan, A., Vuolle, M., \& Sirén, K. (2008). Minimisation of life cycle cost of a detached house using combined simulation and optimisation. Building and Environment, 43(12), 2022-2034.

Iqbal, I., \& Al-Homoud, M. (2007). Parametric analysis of alternative energy conservation measures in an office building in hot and humid climate. Energy \& Environment, 42, 2166-2177.

Kapsalaki, M., \& Leal, V. (2011). Recent progress on net zero energy buildings. Advances in Building Energy Research, 5(1), 129-162.

Kneifel, J. (2010). Life-cycle carbon and cost analysis of energy efficiency measures in new commercial buildings. Energy and Buildings, 42(3), 333-340.

Kurnitski, J., Saari, A., Kalamees, T., Vuolle, M., Niemelä, J., \& Tark, T. (2011). Cost optimal and nearly zero (nZEB) energy performance calculations for residential buildings with REHVA definition for nZEB national implementation. Energy and Buildings, 43(11), 3279-3288.

Lam, J., Wan, K., Tsang, C., \& Yang, L. (2008). Building energy efficiency in different climates. Energy Conversion and Management, 49, 2354-2366.

Levine, M., Urge-Vorsatz, D., Blok, K., Geng, L., Harvey, D., \& Lang, S. (2013). Residential and commercial buildings. In B. Metz, O. R. Davidson, P. R. Bosch, R. Dave, \& L. A. Meyer (Eds.), Climate change 2007: mitigation, Contribution of working group III to the fourth assessment report of the Intergovernmental D.H.W. Li et al. Energy 54 le10 7 Panel on Climate Change (p. 387e446). Cambridge: Cambridge University Press.

Li, D., Yang, L., \& Lam, J. (2013). Zero energy buildings and sustainable development implications - a review. Energy, 54, 1-10. https://doi.org/10.1016/j.energy.2013.01.070.

Marszal, A., \& Heiselberg, P. (2011). Life cycle cost analysis of a multi-storey residential net zero energy building in Denmark. Energy, 36, 9 Pages 5600-5609.

Marta, S., \& Graziano, S. (2013). Overview on life cycle methodologies and economic feasibility for nZEBs. Building and Environment, 67, 211-216, ISSN 0360-1323. https://doi. org/10.1016/j.buildenv.2013.05.022.

Menezes, A., Cripps, A., Buswell, R., Wright, J., \& Bouchlaghem, D. (2014). Estimating the energy consumption and power demand of small power equipment in office buildings. Energy and Buildings, 75, 199-209, ISSN 0378-7788. https://doi.org/10.1016/j.enbuild.2014.02.011.

Mills, E., Friedman, H., Powell, T., Bourassa, N., Claridge, D., Haasl, T., \& Piette, A. (2005). The cost-effectiveness of commercial-buildings commissioning a meta-analysis of energy and non-energy impacts in existing buildings and new construction in the United States. Lawrence Berkeley National Laboratory, Berkeley.

Peterson, K., Torcellini, P., Grant, R., Taylor, C., Punjabi, S., Diamond, R., Colker, R., Moy, G., Kennett, E. (2015). A common definition for zero energy buildings. U.S Department of energy, Energy Efficiency and Renewable Energy.

Pikas, E., Thalfeldt, M., \& Kurnitski, J. (2014). Cost optimal and nearly zero energy building solutions for office buildings. Energy and Buildings, 74, 30-42.

Rahman, M., Rasul, M., \& Khan, M. (2010). Energy conservation measures in an institutional building in sub-tropical climate in Australia. Applied Energy, 87, 2994-3004. 
Reed Business Information (n.d.) RSMeans construction data http://www.rsmeans.com/index.asp (accessed 26.08.07).

Sartori, I., Napolitano, A., \& Voss, K. (2012). Net zero energy buildings: a consistent definition framework. Energy and Buildings, 48, 220-232.

US DOE. (2008). Building Technologies Program, planned program activities for 2008-2012. US: Department Of Energy http://www1.eere.energy.gov/buildings/mypp.html. Accessed March 2016.

Publisher's note Springer Nature remains neutral with regard to jurisdictional claims in published maps and institutional affiliations. 